\title{
Watershed and Stream Network Analysis: A Case Study of Kosi River in Almora District, India
}

\author{
Priyanka Rani, Sushma Bisht*, Dharmendra Singh and Priya Tiwari
}

Department of Science \& Technology, Haryana Space Applications Centre (HARSAC), Haryana, CCS HAU Campus, HISAR 125004, India University of Agricultural and Horticultural Sciences, Shimoga-577204, Karnataka, India

*Corresponding author

\section{A B S T R A C T}

\section{Keywords}

Digital Elevation Model (DEM),

Watersheds, Delineation, Slope and GIS

Article Info

Accepted:

20 November 2019

Available Online:

10 December 2019
Watersheds are natural hydrological entities that cover a specific aerial expanse of land surface from which the rainfall runoff flows to a defined drain, channel, stream or river at any particular point. In the last two decades, watershed management has gained the top most priority in water resources sector necessitating delineation of watersheds upto mini watershed level in order to take up watershed development and management programmes. Prerequisite for watershed management is knowledge of watershed characteristics like slope, relief, aerial extent and drainage networks. Geographic Information systems (GIS) with Digital Elevation model (DEM) can be used for the computation of various watershed characteristics effectively and efficiently than manual computation which is tedious and time consuming. Kosi is the main river of Almora district. SRTM (Shuttle Radar Topographic Mission) data of $30 \mathrm{~m}$ resolution was used for stream network analysis of Kosi river in Kumaon division. In this study an attempt is made to illustrate watershed and stream network delineation of Kosi river in Almora district based on digital elevation models using the hydrology tool in the ArcGIS Geo-processing toolbox. This study also reveals the relationship between other spatial features.

\section{Introduction}

Watershed is the area of land where all of the water that falls in it and drains off it goes to a common outlet (Bose et al., 2011). Watershed can be as small as a footprint or large enough to encompass all the land that drains water into rivers. Watershed has emerged as the basic planning unit of all hydrologic analyses and designs. Each watershed shows distinct characteristics which are of so much variable that no two watersheds are identical. The terms region, basin, catchment, watershed etc. are widely used to denote hydrological units. 
Soil and Land Use Survey of India (SLUSI) preferably used the term watershed in their publication "The National level watershed atlas" in which they reported watershed information on a 1:1 million scale. Even though these terms have similar meanings in popular sense, technically they are different. Size of a watershed is governed by the size of the stream occupied by it. Streams are important component of watershed and present in the form of network.

A network is a system of linear feature that has the appropriate attribute for the flow of object. A network is a system of interconnected elements, such as line connecting points. Networks are all around us. Rivers, Roads, Railways, Cables, Pipelines, Streams and even Glaciers are phenomena that frequently need to be represented and analysed as a network. Networks are used to move people, transport goods, communicate information and control the flow of matter and energy. It is not surprising then, that techniques have been developed to analyse these most important entities for understanding various geographical phenomena (Jiang, 2011) of a drainage basin. Drainage basin is a geo-hydrological unit area draining to a common point considered as an ideal unit for analysis and environmental planning in any ridge to valley treatment. The knowledge of basin hydrology is essential for proper management of water resources and flood hazard in a basin depends upon the hydrological response of the upstream basin area. A drainage system is the pattern formed by streams, rivers, and lakes in a drainage basin. As an indivisible part of land, drainage system is an important component of terrain analysis (Pawar, et al., 2014).

A goal of stream hydrology and ecology is to understand how the spatial structure of stream networks affects the movement of water, energy, and organisms. For spatial analysis of stream network topology (i.e., size and proximity of connected streams), it is necessary to quantify the effects of stream networks and to compare these effects across large watersheds or regions (Betz, et al., 2010). Stream networks exhibit a hierarchically-branched structure wherein conditions at one point in the network may be influenced by conditions in connected streams. Spatial patterns of precipitation and landform features in upstream areas affect flow traveltime and volume at downstream pour-points (Moussa, 2003). This is also important to understand the process of surface runoff and its estimates.

Surface runoff is one of dominant factors in hydrological environment, whose spatial distribution pattern and hydrological feature represent the composite factors of its corresponding drainage and the stream network nodes present spatial structure and attributes of geography and hydrology in a watershed. This study depicts runoff and stream network importance in the hydrology of Almora district. Digital Elevation Model (DEM) digitally demonstrates the elevation variations of earth's surface. In addition, it is the basic data source for terrain analysis and it is an effective analysis method. Now DEM is playing an important role in hydrologic and topographic character analysis. Up to the present, great progress is achieved in river network based on DEM and it is an efficient way to extract river network which is considered as important factor for understanding watershed level hydrology. Some efforts are made to derive terrain features, including peak, pit, ridge, channel, plane, and pass, based on terrain analysis. Moreover, the hydrographical characteristics are extracted, including stream-channel networks, delineation of catchment boundaries, catchment area, catchment length and stream order, based on the flow accumulation method. As the confluence of 
streams, the stream network nodes imply both geographical features and a lot of spatialtemporal messages. So, this study proposes the concept of stream network node, probes into its features and analyses law of stream runoff.

\section{Study area}

The Study Area is located in the kumaun Region of Almora close to the Almora town Latitude is $29^{\circ} 30^{\prime} 00^{\prime \prime}$ to $29^{\circ} 50^{\prime} 30^{\prime \prime}$ North and Longitude is $79^{\circ} 30^{\prime} 00^{\prime \prime}$ to $79^{\circ} 50^{\prime} 00^{\prime \prime}$ East which is shown in Figure 1. Kumaun is a mountainous region of eastern Uttarakhand in India. This region consists of the great Himalayan tract. Many rivers and their tributaries got their course from here. Four major rivers Kali, Western Ramganga, Kosi and Gaula make the surface drainage of Kumaun Himalaya. Kosi is the main river of Almora and Nainital Districts. Kosi and Western Ramganga is the major Himalayan River, which descended from the hills to the plain of Uttarakhand. These river springs fed and Kali is glacier fed as a result the water of Kosi River is comparatively warmer than the glacier Rivers. Kosi River originates in the middle Himalayas of Kumaun region of Uttarakhand. The word Kosi refers "river". Kosi is a Himalayan river which originates from Koshimool near Kausani and flows on the central part of Almora and the western part of Nainital District. Kosi River leaves hills of Kumaun at the plains of Ramnagar and confluences to river Ramganga near village Chamraul Tehsil Shahabad of District Rampur (U.P.). River Kosi has the total catchment area of 3,420 sq. $\mathrm{km}$.

\section{Materials and Methods}

SRTM (Shuttle Radar Topography Mission) data which were downloaded from USGS, with resolution of $30 \mathrm{~m}$. This data were used for stream network analysis in kosi river of kumaon division. The DEM was filled first.
Then this subjected to the generation of flow direction. The flow direction was used to create flow accumulation which was further utilised for the generation of stream and stream order using Strahler algorithm. One of the first attributes to be quantified the hierarchy of stream segments according to an ordering classification system proposed by Strahler, 1957. In this system, channel segment were ordered numerically from a stream headwater to a point somewhere down stream. Numerical ordering begins with the tributaries at the streams headwater being assigned to the value 1 . A stream segment that resulted from the joining of two $1^{\text {st }}$ order segment was given an order of 2 . Two $2^{\text {nd }}$ order streams from a $3^{\text {rd }}$ order stream and so on. The trunk stream through which all discharge of water passes is therefore the stream segment is of the highest order. The number of stream segments present in each order along with their length is recorded in the topology built by GIS.

Stream network map for each of 56 mini watersheds have been created in GIS environment using analysis tool shown in Figure 7. Kosi watershed map, stream network map, and mini watersheds boundary map have been prepared using ArcGIS 10.2. The methodology adopted for Stream network analysis is presented in Figure 2.

\section{Steps and terms followed in the methodology are described below}

\section{Digital elevation model}

DEM are used often in GIS and the most common basis for digitally produced relief map. In hydrology a DEM is the basis for computing waters. However irregularities in the data can perturb the result so that computed water flows wander in and out of known stream channels. It shows the elevation of surface basically region are divided in to 
high and low terrain which are useful for easily analysis stream network. Elevation high value is 2714 metre to low value is 1017 metre as shown in Figure 3.

\section{Flow direction}

Flow direction determines which direction water will flow in given cell based on the direction of the steepest descent in each cell, we measure flow direction. In addition the Zvalue difference and slope are calculated between neibouring cells. In a given cell, water can flow to one or more of eight adjacent cells. Slope is the ultimate factor how water flows in this model. We used a pourpoint model to show how and which direction water travels shown in Figure 4 (a).

The eight adjacent cell in the pour-point model has a value expressing the way in which water falls. Water flows in the east direction, it has a value of 1 , water flows west direction, it has a value of 16, all eight adjacent direction at a given point can be described using the eight direction pour-point model. Running the flow direction algorithm, the resulting value range from $1,2,4,8,16$, 32, 64 and 128 as shown in Figure 4.

\section{Flow accumulation}

It is describe about the Upper Cell Counts which shows the upper value of water pixel then stream are shown accumulation of high value water. Small stream are also plays main role analysis in stream network clearly shows accumulation in Figure 5.

\section{Sink}

A sink is a cell or set of spatially connected cells whose flow direction cannot be assigned one of the eight valid values in a flow direction raster. This can occur when all neighbouring cells are higher than the processing cell or when two cells flow into each other, creating a two-cell loop. Sink are considered to have undefined flow direction and are assigned a value that is the sum of their possible directions. The steepest drop and therefore, flow direction are the same to both the right 1 and left 16 , the value 17 would be assigned as the direction for that cell.

\section{Stream ordering}

Stream ordering is a method of assigning a numeric order to links in a stream network. This order is a method for identifying and classifying type of streams based on their number of tributaries some characteristic of streams can be inferred by simply knowing their order. First- order streams are dominated by overland flow of water; it is upstream concentrated flow.

\section{Bifurcation ratio}

Bifurcation ratio related to the branching pattern of the drainage network is defined as a ratio of the number of stream of a given order to the number of streams of the next higher order. It is supposed to be controlled by drainage density, stream entrance angles, lithological characteristics, basin shape, basin area etc.

\section{Catchment area}

Catchment area is usually linked with rivers in hydrology, as this area states the region from a river usually gets its water or pour out, that can vary from rivers to lakes be in meters or in kilometre.

\section{Results and Discussion}

The morphometric parameter of kosi river basin have been examined and the result are given below. The drainage pattern is dendritic 
in nature and it is inclined by the topography of the area.

\section{Flow direction}

Flow direction map of kosi river basin was prepared by using DEM dataset. Water flows in the direction of the steepest downhill gradient. In DEM dataset, every pixel is potentially surronded by eight neihbouring pixel. The slope in each of these eight neighbouring locations and the value at the pixel are being examined. The present study area flow direction value is 1 to 128 calculated by DEM data. This difference in elevation is then divided by the center to center distance between directions of water flow. The flow direction at every point throughout delineating watershed was determined. The analysis reveals that the flow direction is mostly towards western side as shown in Figure 4.

\section{Flow accumulation}

The Flow Accumulation is a raster of accumulated flow to each cell, as determined by accumulating the weight of cell that flow into each down slope cell, the accumulated flow is based on the number of cells flowing into each cell in the output raster. In graphic below, the left image shows the direction of travel from each cell and the right the number of cell that flow into each cell. Cells with a high flow accumulation are areas of concentrated flow and identify stream channels. Cells with a flow accumulation of 0 are local topographic highs. The procedure to create a raster where the value high 91587 is shown in Figure 5 represents the streams.

\section{Stream ordering}

Stream Ordering is the quantitative analysis of watershed. In the present study ranking of streams has been carried out based on the method proposed by Strahler; in this application, they refered to as the Strahler stream order are used to define stream size based on a hierarchy of tributries. The streams order are classified up to four order in study area. Details of stream order of several tributaries of kosi river and their sub watershed area are shown in the Figure 6. The maximum Stream order frequency is observed in case of first order streams and then for second order. Hence, it is noticed that there is a decrease in stream frequency as the stream order increases and vice versa.

\section{Bifurcation ratio}

Bifurcation values are ranging from 1 to 21 . The higher values of 2 and 3 order streams indicate well developed stream network. The bifurcation values in the 4 order are very low compared to the overall bifurcation ratio of the basin. Bifurcation values ranging from 1 to 21 suggest that it is a natural river system where uniformity is seen with respect to climate, rock type and stage of development.

\section{Catchment area}

The total drainage area of study area basin is $743.02 \mathrm{Km}^{2}$. The drainage pattern is dendritic in nature and it is influenced by the general topography, geology and rainfall condition of the area. These are divided into various streams, catchment basin as shown in Figure 7. With the help of small streams basin we can easily analyze the stream network. Each basins are formed of different morphometary which are according to streams length and its occupied area. The result includes a catchment grid where the sub-catchments area draining directly to each link is assigned a unique value the same as the link it drains to. This allows a relational association between lines in the stream link grid and areas in the catchments grid. 
Table.1 Stream order and number

\begin{tabular}{|c|c|c|c|c|c|}
\hline $\begin{array}{c}\text { Order } \\
\text { Stream }\end{array}$ & $\begin{array}{c}\text { No. of } \\
\text { Stream }\end{array}$ & $\begin{array}{c}\text { Bifurcation } \\
\text { Ratio }\end{array}$ & $\begin{array}{c}\text { Stream } \\
\text { Length } \\
(\mathbf{k m})\end{array}$ & $\begin{array}{c}\text { Mean } \\
\text { Stream } \\
\text { Length } \mathbf{( k m})\end{array}$ & $\begin{array}{c}\text { Stream } \\
\text { length } \\
\text { Ratio }\end{array}$ \\
\hline 1 & 50 & - & 134.230 & 2.68 & 33.55 \\
\hline 2 & 27 & 1.85 & 71.930 & 2.66 & 17.98 \\
\hline 3 & 21 & 1.28 & 55.851 & 2.65 & 13.96 \\
\hline 4 & 1 & 21.00 & 1.501 & 1.50 & 0.37 \\
\hline
\end{tabular}

Fig.1 Study area of Kosi River Almora in Uttarakhand

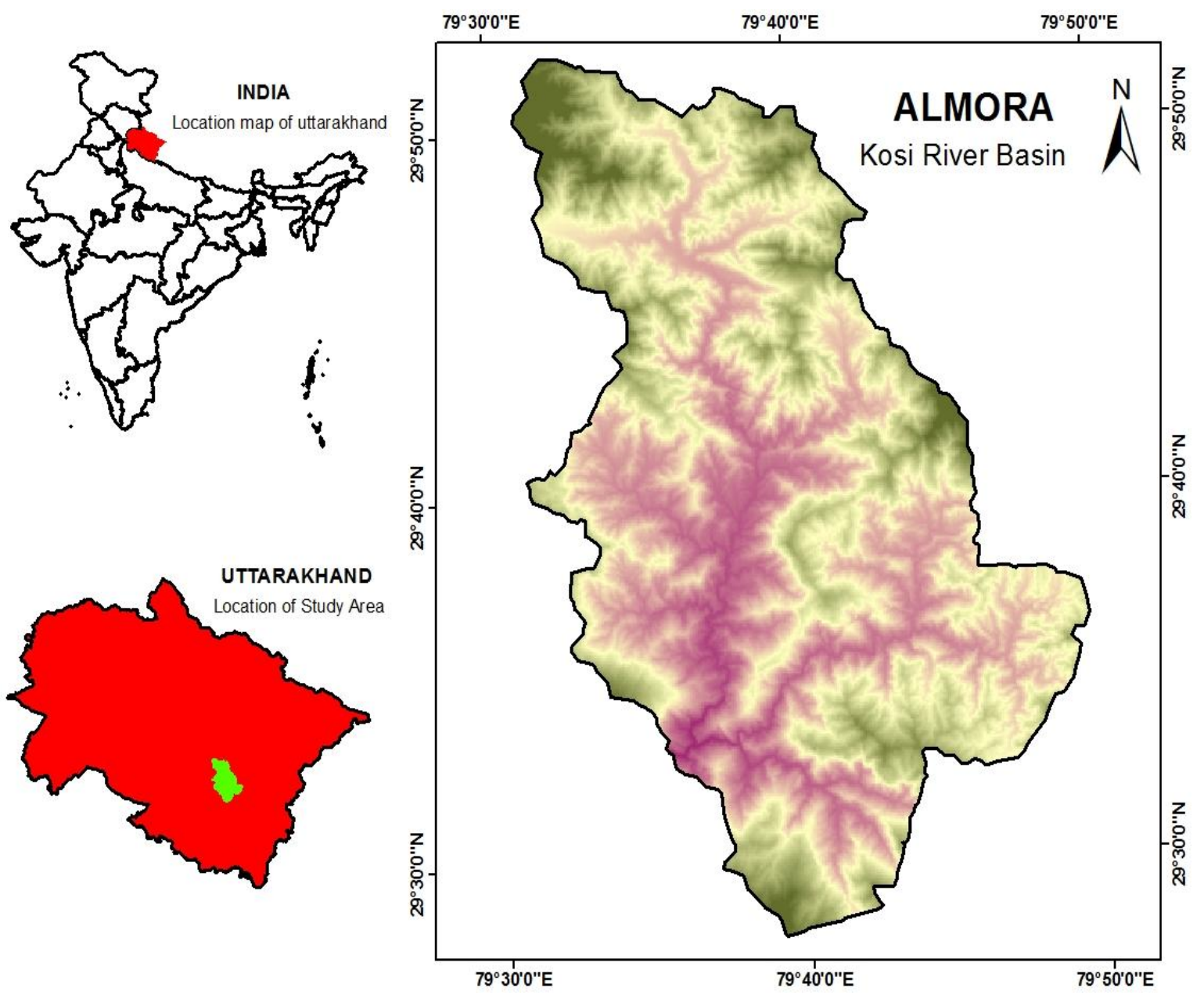


Fig.2 Methodology flow chart

\section{DATA COLLECTION}

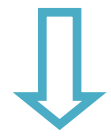

\section{Digital Elevation Modal}

(DEM)

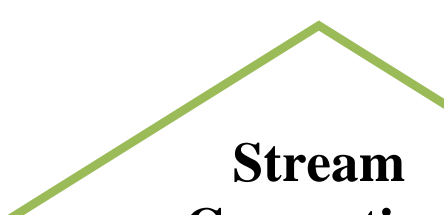

Generation

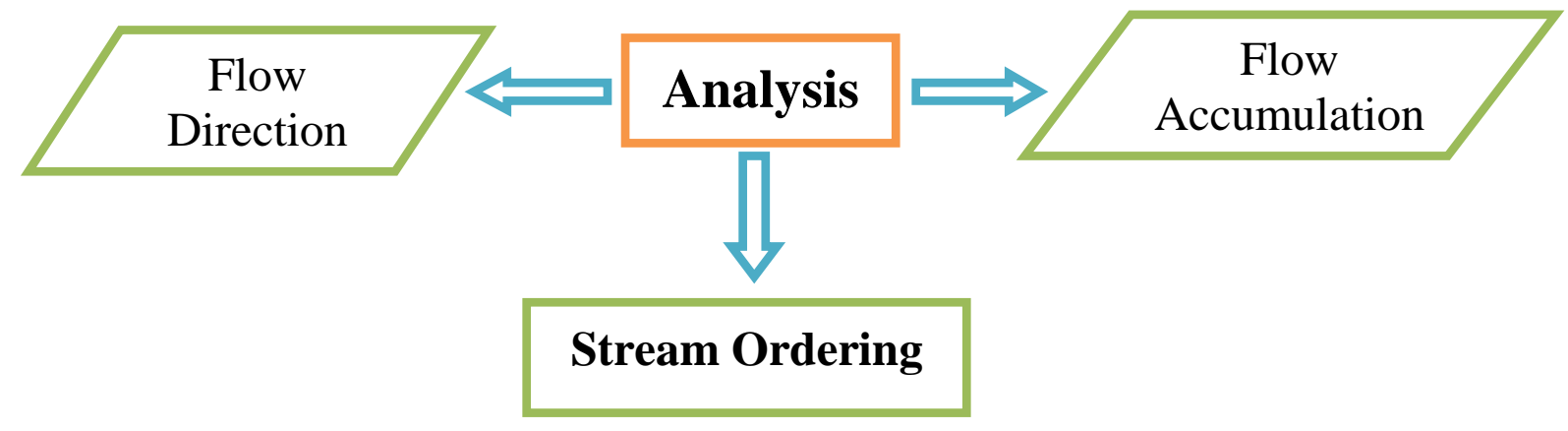

\section{Create Watershed/ Sub watershed}


Fig.3 Digital Elevation Model (SRTM)

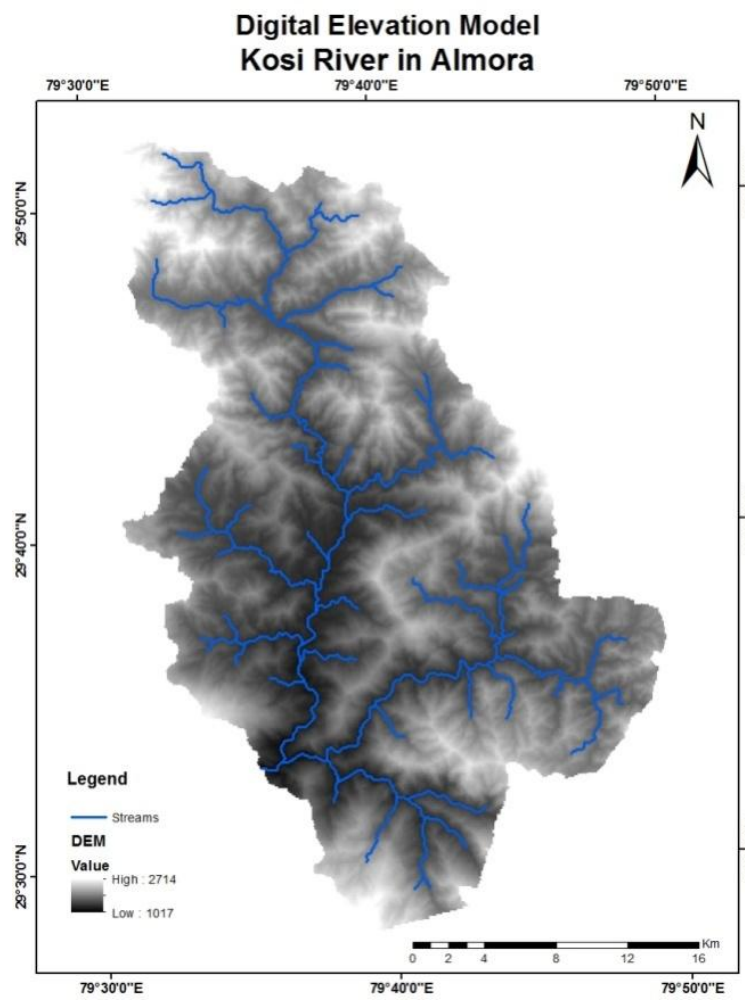

Fig.4 Flow Direction

Flow Direction

Kosi River in Almora

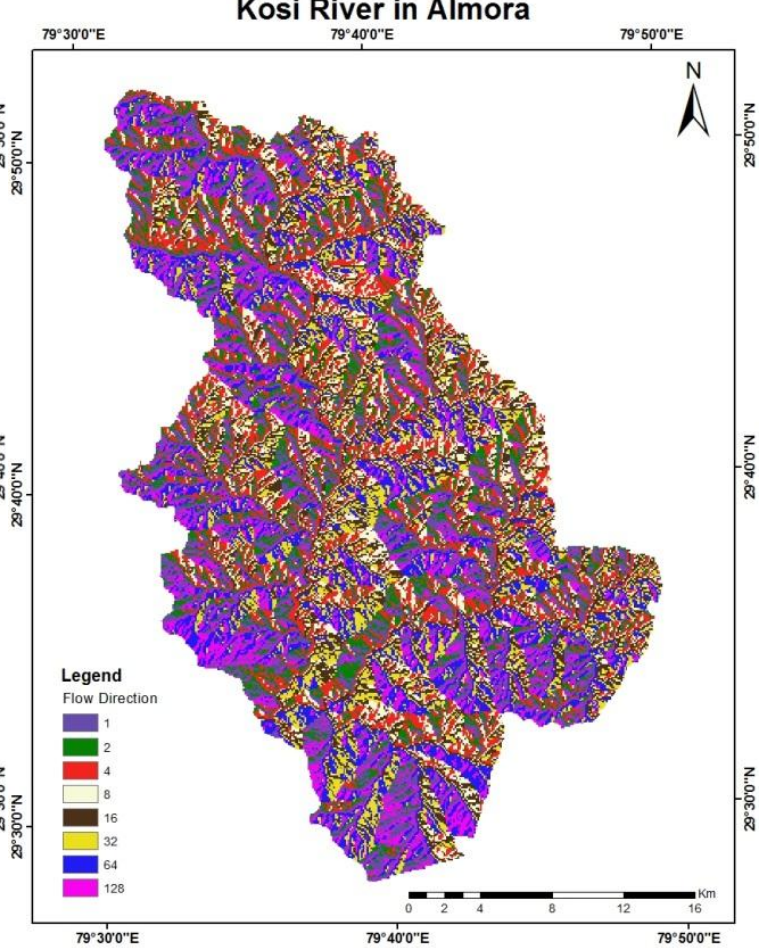

Fig.4(a)

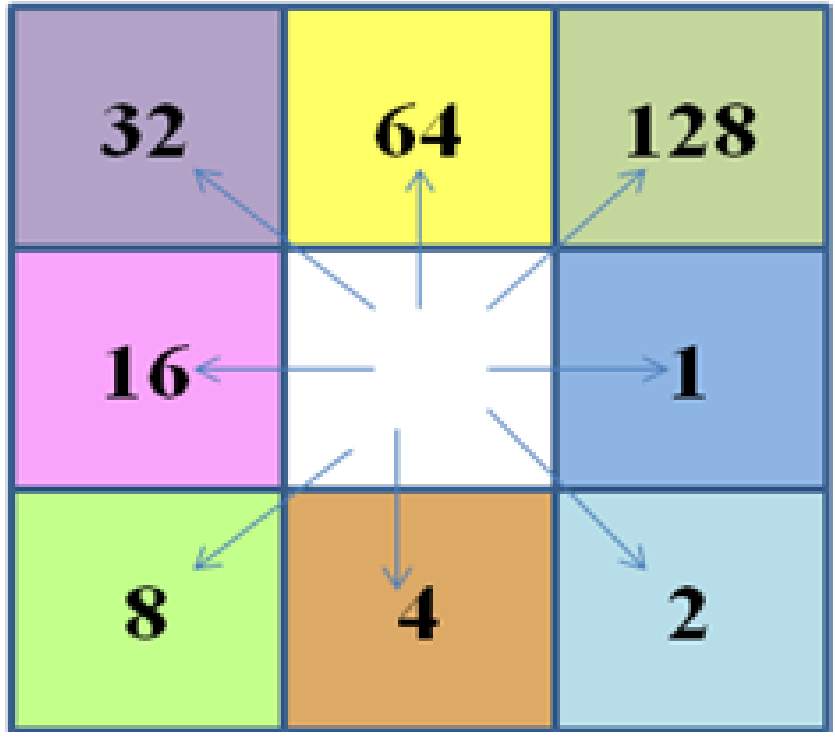


Fig.5 Flow Accumulation

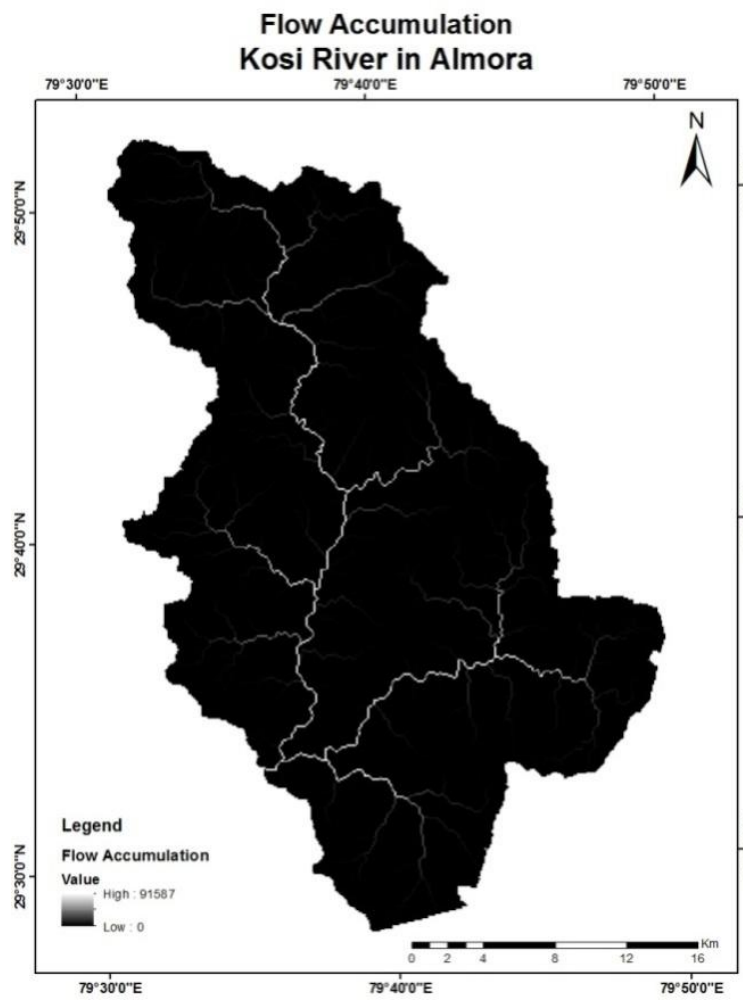

Fig.6 Stream Ordering

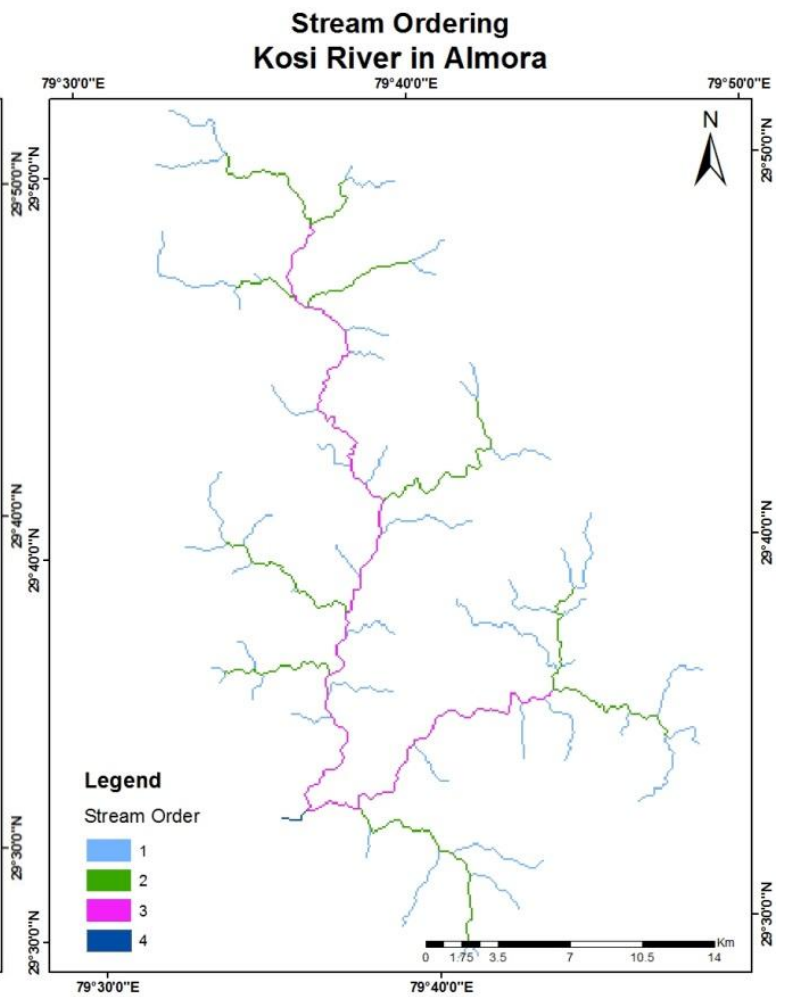

Fig.7 Catchment area of Kosi River

Catchment Area Kosi River in Almora

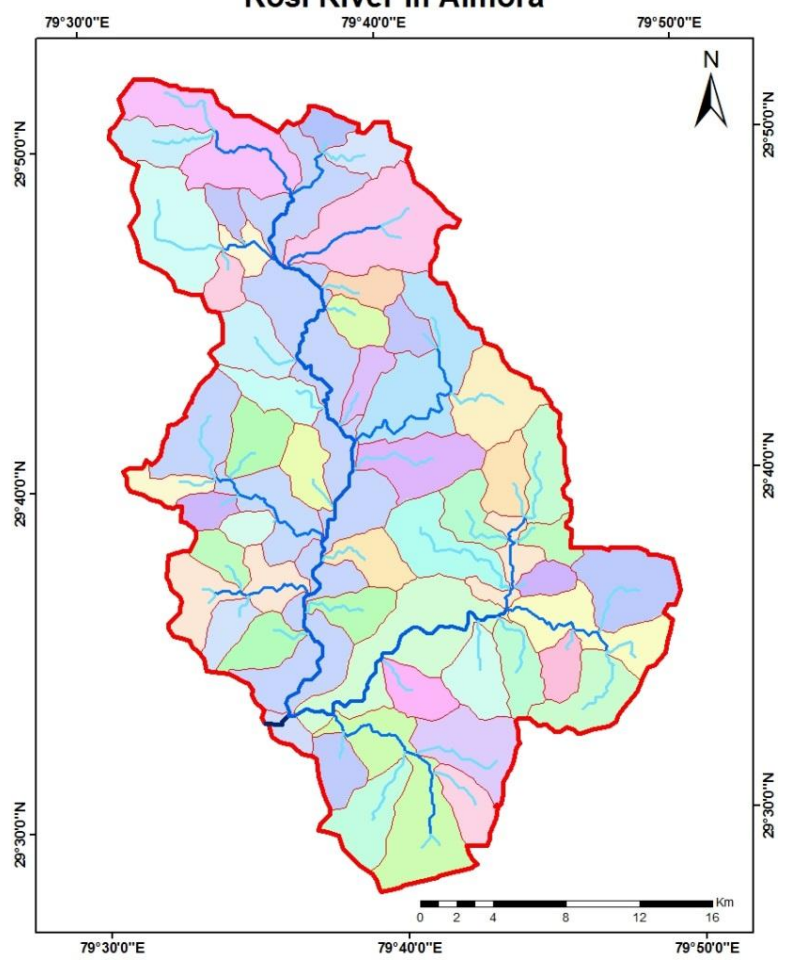




\section{Stream length Ratio}

It is obtained by divided the total length of stream of an order by the total number of segments in the order.

As per law of stream number the number of streams decreases as the stream order increases. Stream order number relationship shown in Table 1 suggests that $1^{\text {st }}$ order streams are more in number.

In case of kosi river there are 50 first order streams which give rise to 27 second order streams as well as 21 third order streams and 1 fourth order and these have developed the main stream in study area. The present study area proved that the RS and GIS technique used for computation and analysis of various hydrologic parameter of the basin and helps to understand various terrain parameters such as surface infiltration capacity, runoff etc. The kosi river is well drained in nature with the stream order varying 1 to 4 . The basin is dominated by lower order streams and the total length of stream segments. Stream frequency and drainage density is the prime criterion for the metamorphic classification of drainage basin, which certainly control the runoff pattern and other hydrological parameters of the drainage basin. Hydrologic parameters have been calculated with the help of ArcGIS- 10.2 software. The bifurcation ratio range is $1.85-21$ and the total bifurcation ratio is 24.13. The quantitative analysis of linear, relief and aerial parameters using GIS and RS techniques is found to be of immense utility in river basin evaluation, basin prioritization for soil and water conservation and natural resource management. The bifurcation ratio in basin indicates normal basin category and the presence of moderate drainage density suggesting that, it is moderate permeable subsoil and coarse drainage texture. The hydrologic analysis of the drainage network of the basin show dendritic to sub dendritic drainage patterns with drainage texture. The variation in stream length ratio might be due to change in slope and topography.

The hydrologic analysis is carried out in four stream order of kosi river basin using RS and GIS techniques for determining the linear aspect such as stream order, bifurcation ratio and stream length. The difference in stream length ratio might be due to change in slope and topography. The basin is having moderate to high relief of the terrain and elongated in shape. Remote sensing and GIS techniques have best efficient tool in drainage delineation.

The conventional methods of hydrological analysis are time consuming and error prone, while use of GIS method allows for more reliable and accurate estimation of similar parameters of kosi river basin.

Moreover, the stream network is fractal geometry. By measuring dimension of the stream network node and compared with other parameter, it finds that dimension of stream network node is the reflection of development and erosion of the watershed. The first and second stream order is of high priority stream and is prone to comparatively higher erosion and soil loss.

\section{References}

Betz, R., Hitt, N.P., Dymond, R.L. and Heatwole, C.D., 2010: A Method for Quantifying Stream Network Topology over Large Geographic Extents. Journal of Spatial Hydrology, Vol. 10, No.1, pp 15-29.

Bose, A.S.C., Sridhar, P., Giridhar, M.V.S.S. and Viswanadh, G.K., 2012: Morphometric Analysis at miniwatershed level using GIS. International Journal of Civil 
Engineering Research, Vol. 3, No. 3, pp 157- 171.

Jiang Y., 2011: GIS Stream Network Analysis for Huaihe River Basin of China. Procedia Environmental Sciences, Vol. 10, pp 1553- 1558.

Moussa, R., 2003: On Morphometric Properties of basins, scale effects and hydrological response. Hydrological Processes, Vol. 17, Issue 1, pp 33-58.
Pawar, A.D., Sarup, J. and Mittal, S.K., 2014: Application of GIS and RS for Morphometric Analysis of Upper Bhima Basin: A case Study. Journal of the Institution of Engineers (India), Vol. 95, Issue 4, pp 249-257.

Strahler, A.N., 1957: Quantitative analysis of watershed geomorphology. American Geophysical Union Transactions, Vol. 38, Issue 6, pp 913-920.

\section{How to cite this article:}

Priyanka Rani, Sushma Bisht, Dharmendra Singh and Priya Tiwari. 2019. Watershed and Stream Network Analysis: A Case Study of Kosi River in Almora District, India. Int.J.Curr.Microbiol.App.Sci. 8(12): 2601-2611. doi: https://doi.org/10.20546/ijcmas.2019.812.304 